\title{
PROGRAM PEMBENTUKAN KARAKTER DISIPLIN PESERTA DIDIK SELAMA PEMBELAJARAN DARING DI SEKOLAH DASAR
}

\section{DISCIPLINE CHARACTER-BUILDING PROGRAM FOR STUDENTS DURING ONLINE LEARNING IN ELEMENTARY SCHOOL}

\author{
Alif Lutfi Ghozali ${ }^{1}$, Bambang Sumardjoko ${ }^{2}$, Achmad Fathoni ${ }^{3}$, Laili Etika Rahmawati ${ }^{4}$ \\ 1,2,3,4Pascasarjana Pendidikan Dasar Universitas Muhammadiyah Surakarta \\ 1,2,3,4J1. Ahmad Yani, Pabelan, Kartasura, Surakarta 57162, Jawa Tengah, Indonesia \\ Email: q200170018@student.ums.ac.id ${ }^{1}, \underline{\text { bs131 @ ums.ac.id }}^{2}, \underline{\text { achmad-fathoni@ums.ac.id }}^{3}$, \\ Laili.Rahmawati@ums.ac.id ${ }^{4}$
}

Submitted: 07-07-2021, Revised: 01-11-2021, Accepted: 15-11-2021

\begin{abstract}
Abstrak
Dampak dari pandemi dalam dunia pendidikan adalah perubahan pola pembelajaran dari luring menjadi daring. Artikel ini bertujuan untuk mendeskripsikan program pembentukan karakter disiplin peserta didik selama pembelajaran daring. Metode penelitian yang digunakan adalah penelitian kualitatif. Teknik Pengumpulan data dalam penelitian ini adalah observasi, wawancara, dan dokumentasi. Pengujian keabsahan data dalam penelitian ini menggunakan triangulasi teknik dan triangulasi sumber serta analisis data dengan cara reduksi data, penyajian data, dan penarikan kesimpulan. Hasil penelitian diperoleh bahwa program pembentukan karakter disiplin peserta didik selama pembelajaran daring dilakukan dengan empat tahap. Tahap pertama adalah perencanaan, pada tahap ini guru membuat RPP dengan mengintegraksikan nilai disiplin pada setiap langkahnya. Tahap kedua adalah pelaksanaan, yakni guru memulai pelajaran sesuai dengan RPP dengan media whatsapp grup, youtube, dan video call. Tahap ketiga adalah evaluasi. Evaluasi dilaksanakan guru dengan tiga teknik, yakni teknik pengamatan, teknik konsultasi wali murid, dan teknik buku kontrol peserta didik. Tahap keempat adalah tindak lanjut, pada tahap ini guru melakukan bimbingan konseling secara private dengan media video call untuk memberikan bimbingan, arahan, dan motivasi pada peserta didik.
\end{abstract}

Kata Kunci: Karakter, Disiplin, Pembelajaran Daring

\begin{abstract}
The impact of the pandemic on education is the change of the learning system from offline to online. This article aims to describe the discipline character-building of students during online learning. The method used was qualitative research. The research's data collection techniques were through observation, interviews, and documentation. This research used technical and source triangulations to validate the data. The analysis data employed data reduction, presentation, and conclusion. The research results indicated that the discipline character-building of students during online learning was carried out in four steps. The first step was planning. At this step, the teacher made lesson plans by integrating the discipline value in each stage of learning. The second step was implementation. The teacher started the lesson based on the lesson plan through whatsapp group, youtube, and video calls. The third was evaluation. The teacher carried out the evaluation using three techniques, namely observation, parenting, and student control book techniques. The fourth step was a follow-up. At this step, teachers did private counseling using video calls and gave students guidance, direction, and motivation.
\end{abstract}

Keywords: Character, Discipline, Online Learning 
How to Cite: Ghozali, A. L., Sumardjoko, B., Fathoni, A., \& Rahmawati, L. E. (2021). Program Pembentukan Karakter Disiplin Peserta Didik selama Pembelajaran Daring di Sekolah Dasar. AULADUNA: Jurnal Pendidikan Dasar Islam, 8(2), 216-231.

\section{Pendahuluan}

Karakter bangsa selama ini belum bisa menggambarkan falsafah dan budaya bangsa, sehingga perlu adanya perubahan mengenai konsep pembangunan sumber daya manusia. Hal ini diperkuat dengan pencanangan program revolusi mental yang menjadi konsep pembangunan sumber daya manusia oleh Presiden Joko Widodo untuk membentuk karakter bangsa Indonesia (Mustaqim, 2015). Isu degradasi moral akhirakhir ini menjadi tantangan besar bagi dunia pendidikan. Degradasi moral sekarang banyak ditemui di lingkungan sekolah, misalkan hilangnya rasa patuh pada guru, menurunnya kedisiplinan, lunturnya kejujuran, dan sifat-sifat lain yang tidak mencerminkan karakter peserta didik saat ini (Rahayu, Narimo, Fathoni, Rahmawati, \& Widiyasari, 2020).

Penuh akan tantangan, kini dunia pendidikan kembali dihadapkan pada suatu tantangan yang berat. Pada tahun 2020, Indonesia bahkan negara di dunia sedang mengalami sebuah bencana kesehatan yaitu dengan adanya Covid-19 yang berdampak pada segala bidang, termasuk dalam bidang pendidikan. Efek dari Covid-19 dalam bidang pendidikan di Indonesia adalah proses kegiatan belajar mengajar ditiadakan secara tatap muka di sekolah dan diubah menjadi kegiatan belajar mengajar secara daring atau dalam jaringan (Mustikaningrum, Pramusinta, Buamona, Cahyadi, \& Istiqomah, 2020). Hal ini dilakukan untuk mencegah semakin meluasnya virus Covid19. Lembaga pendidikan tidak melaksanakan aktivitas pembelajaran tatap muka seperti biasanya. Hal ini diharapkan bisa meminimalisir penyebaran Covid-19 (Anhusadar, 2020).

Perubahan pembelajaran dari tatap muka menjadi pembelajaran jarak jauh secara daring atau online adalah hal yang baru. Kesiapan guru, wali murid, dan peserta didik sangat bervariasi, yakni ada yang siap, ada yang setengah siap, dan ada yang tidak siap sama sekali (Novianti \& Garzia, 2020). Kepemimpinan guru dalam masa darurat ini sangat penting. Cara guru memanajemen waktu dan meningkatkan inovasi pembelajaran bagi peserta didik pada periode ini sangat menentukan kesuksesan dalam mencapai tujuan pendidikan (Sudarmo \& Muslimah, 2020). Guru sekolah dasar terbiasa melaksanakan pembelajaran secara tatap muka. Kondisi ini tentu mengakibatkan ketidaksiapan persiapan pembelajaran. Perubahan yang timbul akibat Covid-19 sangat cepat, sehingga memaksa guru untuk melek terhadap teknologi, karena hanya melalui teknologi guru dapat melaksanakan tugasnya untuk mendidik peserta didik tanpa harus tatap muka (Rigianti, 2020).

Kemampuan dan kreativitas guru sangat menentukan keberhasilan dalam pembelajaran daring. Pemanfaatan media pembelajaran oleh guru juga beraneka macam antara lain whatsapp group, google meet, zoom, google classroom, youtube, dan aplikasi lain untuk menggabungkan video pertemuan (Novianti \& Garzia, 2020; Zakaria \& Maulida, 2021). Media pembelajaran, waktu pembelajaran dengan menggunakan aplikasi, psikis, dan faktor sosial sangat berpengaruh terhadap motivasi guru saat mengajar, namun tugas seorang guru harus mengatasi semua masalah dengan cepat dan tanggap supaya pembelajaran daring tetap mencapai target yang telah ditentukan (Rasmitadila, Aliyyah, Rachmadtullah, Samsudin, Syaodih, Nurtanto, \& Tambunan, 2020). 
Pembelajaran daring menyebabkan guru tidak dapat mengawasi langsung peserta didik, hal ini tentu memberikan dampak pada kualitas nilai-nilai karakter peserta didik. Salah satu yang mengkhawatirkan dari fenomena ini adalah menurunnya nilai dasar yang sangat penting untuk peserta didik, yakni nilai disiplin. Kemerosotan nilai disiplin merupakan masalah besar bagi peserta didik, keluarga, masyarakat, dan bangsa. Permasalahan disiplin tidak hanya masalah sosial semata, tetapi masalah serius dan mengkhawatirkan karena apabila dicermati banyak problem bangsa ini berakar dari persoalan disiplin (Widagdo, Nurdyansah, \& Faujiyah, 2020).

Perlu adanya suatu penguatan nilai-nilai karakter, hal ini dikarenakan dengan banyaknya kejadian yang menunjukkan krisis moral baik di lingkungan keluarga, masyarakat, dan sekolah (Hermanto, Japar, \& Utomo, 2019). Dalam pembelajaran daring, ada beberapa nilai-nilai karakter yang perlu untuk ditekankan, yaitu nilai gemar membaca, cinta tanah air, peduli lingkungan, dan peduli sosial (Purandina \& Winaya, 2020). Beberapa nilai ini nampaknya sulit dikembangkan pada masa pandemi, guru tidak bisa membimbing peserta didik secara langsung. Nilai dasar untuk menumbuhkan nilai-nilai karakter tersebut dimulai dari nilai karakter disiplin. Disiplin menjadi nilai utama yang harus ditekankan sejak dini melalui pembiasaan-pembiasaan positif dalam kegiatan di sekolah maupun di rumah.

Disiplin memiliki arti serangkaian tingkah laku yang menunjukkan nilai kepatuhan, ketaatan, kesetiaan, ketertiban, dan keteraturan. Menurut Bajri, Oktaviani, Luzyawati, Eka, \& Nurfebriani (2021), disiplin merupakan suatu perilaku yang mempunyai hubungan tentang pengendalian diri dan sikap untuk bertanggung jawab terhadap apa yang telah menjadi peraturan. Karakter disiplin mampu membuat seseorang menjadi mengerti mengenai hal apa yang wajib dilakukan, hal yang boleh dilakukan, dan hal yang tidak sepatutnya dilakukan (Sugiarto, Suyati, \& Yulianti, 2019). Disiplin peserta didik merupakan salah satu dasar dari proses belajar mengajar yang efektif (Obadire \& Sinthumule, 2021). Disiplin mendukung seseorang untuk memperoleh ilmu, membentuk sikap, membiasakan, menaruh minat, dan prinsip belajar yang bermanfaat bagi peserta didik dan masyarakat (Ahmad, Qamar, \& Abbasi, 2021). Seseorang yang selalu menjunjung tinggi nilai disiplin akan berhasil pada proses belajar maupun bekerja. Disiplin merupakan kebutuhan bagi setiap manusia, apalagi pada masa kanak-kanak adalah masa yang paling efektif dalam pembentukan perilaku (Aulina, 2013).

Adanya virus Covid-19 menyebabkan pembelajaran dilaksanakan dari rumah merupakan tantangan yang besar bagi guru mengenai pembentukan karakter disiplin peserta didik. Sekolah dengan sistem tatap muka saja masih terdapat peserta didik yang melanggar peraturan, apalagi pada saat pembelajaran daring (Jannah \& Supriyanto, 2021). Karakter disiplin memiliki peran penting dalam pelaksanaan pembelajaran daring, karena disiplin dapat memberikan dampak pada sikap atau perilaku peserta didik. Peserta didik yang memiliki karakter disiplin pasti akan memiliki minat untuk belajar dan berusaha meski tidak bertatap muka dengan guru secara langsung (Nisa, Fathurohman, \& Setiawan, 2021).

Tujuan dari penelitian ini adalah untuk mendeskripsikan program pembentukan karakter disiplin peserta didik selama pembelajaran daring. Pelaksanaan penelitian ini diharapkan dapat menjadi rujukan serta informasi untuk pengambilan suatu kebijakan mengenai implikasi program pembentukan karakter disiplin selama pembelajaran daring. Penelitian ini juga mempunyai tujuan untuk mengetahui media apa saja yang 
digunakan guru selama pembelajaran daring untuk mendukung berjalannya program pembentukan karakter disiplin.

\section{Metode Penelitian}

Jenis penelitian ini adalah penelitian kualitatif. Pada penelitian kualitatif, temuan yang diperoleh melalui prosedur non statistik atau bukan dalam bentuk hitungan dan memiliki tujuan untuk medeskripsikan gejala secara holistik-kontekstual, mengumpulkan data secara alami dengan peran peneliti sebagai instrumen kunci (Sugiarto, 2015). Adapun desain penelitian ini adalah fenemenologi. Fenemenologi merupakan desain penelitian kualitatif yang mencoba mengungkap makna berdasarkan pengalaman. Lokasi penelitian ini adalah di SD Muhammadiyah Program Khusus Andong. Sumber data dalam penelitian ini adalah peserta didik kelas dua, guru kelas dua, guru pendamping, kepala sekolah, dan dokumen-dokemen yang mendukung dalam penelitian ini.

Indikator karakter disiplin yang dinilai dalam penelitian ini adalah ketaatan dan ketertiban peserta didik dalam melaksanakan kegiatan-kegiatan yang menjadi pembiasaan di sekolah. Teknik pengumpulan data dalam penelitian ini adalah observasi, wawancara, dan dokumentasi. Pengujian data menggunakan triangulasi teknik dan triangulasi sumber dengan melibatkan kepala sekolah, guru kelas, dan guru pendamping. Analisis data dalam penelitian ini adalah menggunakan teori Miles and Hubermen dalam Sugiyono (2013) yaitu analisis data kualitatif dilakukan secara interaktif dan berlangsung secara terus menerus sampai tuntas dengan cara reduksi data, penyajian data, dan tahap kesimpulan.

\section{Hasil dan Pembahasan}

\subsection{Hasil}

Berdasarkan pada hasil penelitian yang telah dilaksanakan di SD Muhammadiyah Program Khusus Andong, peneliti menemukan hasil yang menunjukkan bahwa dalam kondisi pembelajaran daring, program pembentukan karakter disiplin peserta didik dilaksanakan secara empat tahap. Dari data yang diperoleh, empat tahap dalam program pembentukan karakter disiplin peserta didik selama pembelajaran daring di SD Muhammadiyah Program Khusus Andong adalah sebagai berikut:

\subsubsection{Perencanaan}

Pada tahun 2020, Kemendikbud mengeluarkan surat edaran nomor 4 tahun 2020 yang berisi mengenai pelaksanaan pendidikan pada masa darurat Covid-19. Surat edaran tersebut dikeluarkan karena semakin merebaknya virus Covid-19 di Indonesia. Surat tersebut berisi sistem pembelajaran yang semula dilaksanakan secara tatap muka harus berubah menjadi sistem jarak jauh dengan cara daring. Hal tersebut dilakukan dengan tujuan untuk memutus mata rantai penyebaran virus Covid-19. Pernyataan mengenai perubahan sistem pembelajaran juga disampaikan oleh Kepala Sekolah SD Muhammadiyah Program Khusus Andong sebagai berikut:

"Berdasarkan surat edaran dari Kemendikbud dan dari Majelis Dikdasmen Pimpinan Pusat Muhammadiyah, maka SD Muhammadiyah Program Khusus Andong melaksanakan pembelajaran secara daring bagi peserta didik, sedangkan 
untuk guru apabila dalam kondisi sehat dianjurkan tetap masuk sekolah untuk melaksanakan pembelajaran di sekolah. Hal ini dikarenakan sarana penunjang pelaksanaan pembelajaran daring disediakan di sekolah".

Pernyataan kepala sekolah tersebut menjelaskan bahwa peserta didik belajar dari rumah dengan menggunakan sistem daring, sedangkan guru tetap masuk ke sekolah. Hal ini juga didukung oleh hasil observasi peneliti yang menyebutkan bahwa peserta didik belajar dari rumah, sedangkan guru tetap berangkat setiap hari. Guru dalam setiap kelas di SD Muhammadiyah Program Khusus Andong terdiri dari dua guru, yakni guru kelas dan guru pendamping, sehingga perlu adanya diskusi dan persiapan bersama untuk melaksanakan pembelajaran daring setiap hari.

Fenomena pembelajaran daring menyebabkan sebagian besar peserta didik mengalami kemerosotan mengenai nilai-nilai karakter. Tidak sedikit peserta didik menganggap pembelajaran daring adalah libur sekolah. Pembentukan karakter selama pembelajaran daring di SD Muhammadiyah Program Khusus Andong ditekankan dengan tujuan memberikan kekuatan dasar karakter disiplin bagi peserta didik sejak dini, sehingga peserta didik memiliki pondasi yang kuat dalam kondisi apapun dan kelak menjadi pribadi yang unggul dan berkualitas.

Pembentukan karakter disiplin peserta didik bukanlah hal yang mudah, terlebih saat ini pendidikan juga terdampak besar akibat adanya virus Covid-19. Perlu adanya perencanaan yang matang mengenai konsep pembelajaran dan media yang digunakan. Pertanyaan mengenai perencanaan program pembentukan karakter disiplin peserta didik selama pembelajaran daring juga peneliti tanyakan kepada guru kelas II. Jawaban mengenai perencanaan program pembentukan karakter disiplin peserta didik selama pembelajaran daring dari guru kelas II adalah sebagai berikut:

"Pada tahap perencanaan, saya bersama dengan guru pendamping melakukan penyusunan konsep, antara lain: (1) membuat RPP dengan mengintegrasikan nilai karakter disiplin dalam langkah-langkah pembelajaran, (2) pembuatan video untuk diunggah di youtube sesuai dengan isi RPP kemudian dilanjutkan untuk dibagikan di whatsapp group, (3) membuat strategi dan teknik evaluasi, dan (4) membuat langkah-langkah tindak lanjut bimbingan yang berdasar dari hasil evaluasi"”.

Guru pendamping juga memberi penjelasan akan hal tersebut, beliau menyatakan:

"Tahap perencanaan ini kami mulai dengan RPP dengan menekankan nilai disiplin pada setiap langkah-langkahnya, kedua yaitu saya bersama guru kelas bekerja sama untuk membuat video pembelajaran, ketiga adalah menentukan strategi dalam evaluasi, dan yang keempat adalah membuat tindak lanjut”.

Perencanaan adalah proses yang sangat penting dalam sebuah program. Pada tahap perencanaan, akan terlihat jelas tujuan dan arah program tersebut. Dalam kaitannya dengan program pembentukan karakter disiplin peserta didik selama pembelajaran daring, konsep yang disampaikan oleh guru kelas dan guru pendamping merupakan standar proses yang harus dipenuhi. Tetapi dalam pelaksanaan, inovasi dan improvisasi dapat dikembangkan sebaik mungkin agar peserta didik tidak mengalami 
kejenuhan. Kunci sukses program pembentukan karakter disiplin peserta didik selama pembelajaran daring adalah dengan mematangkan suatu perencanaan dan berkolaborasi dengan semua pihak, baik dari pihak sekolah maupun keluarga di rumah. Ketika perencanaan sudah berjalan dengan baik, dan kolaborasi antara guru dengan wali murid berjalan efektif, maka pembelajaran daring bukan suatu halangan untuk membentuk karakter disiplin peserta didik.

\subsubsection{Pelaksanaan}

Penguasaan teknologi memang menjadi suatu keharusan dalam implementasi pembelajaran daring. Wali murid, peserta didik, dan guru ditekankan untuk mampu menggunakan teknologi demi suksesnya pembelajaran daring. Urutan pelaksanaan program pembentukan karakter disiplin peserta didik selama pembelajaran daring disampaikan oleh guru kelas dalam kutipan hasil wawancara sebagai berikut:

"Pembelajaran kami mulai pada pukul 07.30 WIB. Kami mengawali dengan menyapa peserta didik melalui whatsapp group kelas dan meminta peserta didik untuk memberikan absen kehadiran dengan mengirim foto atau video kegiatan pagi harinya, mulai dari membantu orang tua dan sholat dhuha sebelum pelajaran dimulai. Kegiatan ini dilakukan sebagai ganti dari kegiatan sehari-hari ketika pembelajaran dilaksanakan secara luring di sekolah. Kami mengumumkan urutan pembelajaran pada hari itu dengan mengirim link video di youtube yang berisi video pembelajaran, baik video pembelajaran mata pelajaran umum maupun al-islam kemuhammadiyahan. Guru pendamping menambahkan untuk membagi kelompok bimbingan belajar setelah video pembelajaran selesai disimak oleh peseta didik".

Demikian pula pernyataan serupa disampaikan oleh guru pendamping, beliau menyatakan bahwa:

"Pembelajaran dimulai pukul 07.30 WIB melalui whatsapp grup oleh guru kelas dengan menyampaikan salam dan meminta peserta didik untuk melakukan absen dengan meminta bukti video atau foto pembiasaan pagi seperti di sekolah, yakni sholat dhuha dan membantu orang tua piket di rumah sebagai ganti piket di kebersihan di kelas. Dilanjutkan dengan pembagian link video pembelajaran dan pembagian kelompok untuk review pembelajaran melalui video call".

Pembelajaran daring merupakan sesuatu yang baru. Guru tidak bisa memantau langsung kegiatan peserta didiknya, tetapi dengan kemajuan teknologi seperti apa yang disampaikan oleh guru kelas dan guru pendamping dalam kutipan wawancara tersebut yang menjelaskan bahwa pembiasaan pagi sebelum pembelajaran tetap bisa dilakukan, guru tetap bisa memantau kegiatan peserta didik menggunakan media whatsapp grup. Guru dapat mengirim tugas pembiasaan pagi hari melalui whatsapp grup dan meminta laporan akan tugas yang diberikan melalui bukti foto atau video dengan mudah dan cepat. Pada penyampaian materi pelajaran, guru juga berinovasi dengan membuat video pembelajaran yang diunggah melalui channel youtube. Peneliti juga mendapatkan arsip dokumentasi pembelajaran guru melalui video yang telah diunggah di youtube. Dokumentasinya adalah sebagai berikut: 


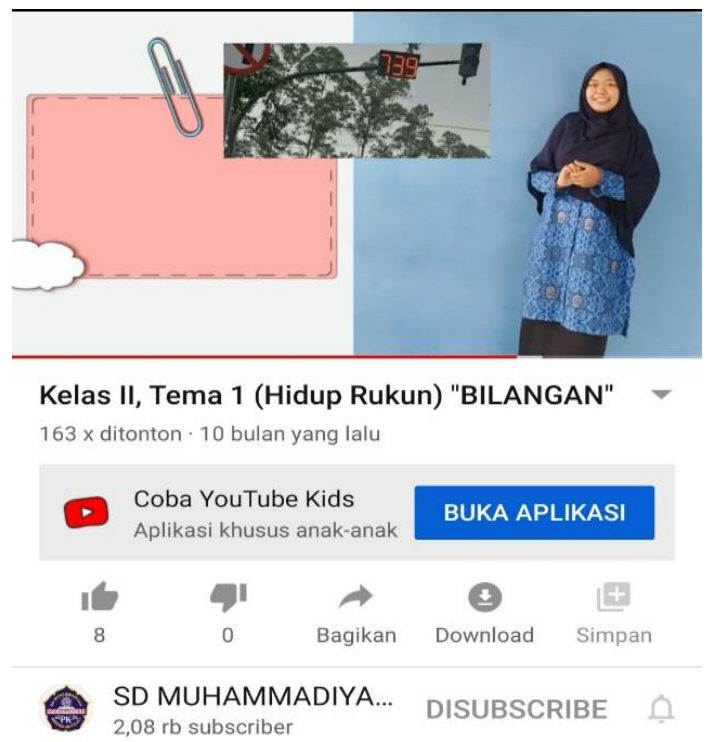

Gambar 1. Video Pembelajaran Guru melalui Youtube

Video pembelajaran tersebut ditonton dan dipahami secara mandiri oleh peserta didik. Setelah selesai memperhatikan materi pembelajaran yang disampaikan guru melalui video, peserta didik mulai mempersiapkan diri untuk menerima panggilan video call dari guru kelas dan guru pendamping. Video call dilakukan oleh guru tepat sesuai dengan jadwal yang telah dibagi untuk masing-masing kelompok yang telah dibagi oleh guru. Guru kelas dan guru pendamping akan memberikan umpan balik mengenai materi dalam video youtube yang telah diperhatikan peserta didik untuk menguji apakah peserta didik memperhatikan dan mengikuti video pembelajaran dengan baik atau tidak, lalu dilanjutkan dengan pemberian soal evaluasi untuk dikerjakan dan dikumpulkan sesuai dengan waktu yang ditentukan. Selain memberikan umpan balik, peserta didik juga boleh bertanya mengenai materi yang belum dipahami saat video call berlangsung.

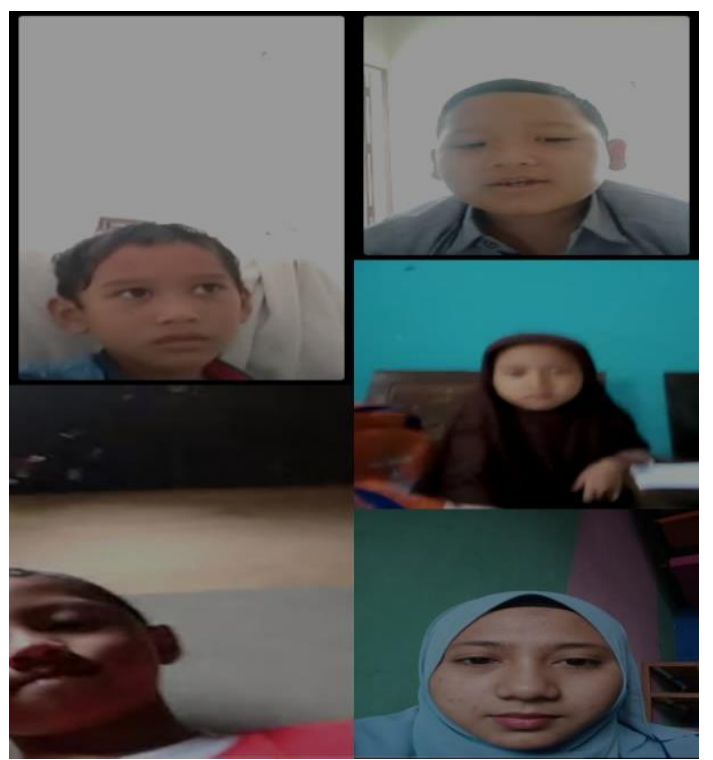

Gambar 2. Video Call secara Kelompok Guru Pendamping dengan Peserta Didik 
Berdasarkan hasil observasi peneliti, video call yang dilakukan guru dengan peserta didik juga dilakukan dengan tujuan untuk memberikan reward kepada peserta didik yang telah taat dan tertib mengikuti pembelajaran di hari sebelumnya serta memberikan punishment bagi peserta didik yang kurang disiplin berdasarkan penilaian dari guru kelas dan guru pendamping.

Terdapat berbagai kendala yang dihadapi oleh guru dalam pelaksanaan program pembentukan karakter disiplin peserta didik selama pembelajaran daring. Kendala tersebut disampaikan oleh guru kelas II dalam kutipan wawancara sebagai berikut:

"Kendala dari dalam sekolah misalnya selama pandemi diklat atau pelatihan terhadap guru sangat minim dikarenakan untuk menjaga dan menghindari kerumunan, sehingga guru dalam melaksanakan pembelajaran daring menggunaan pelatihan otodidak. Kendala dari faktor luar sekolah adalah kondisi geografis yang mengakibatkan sebagian besar peserta didik mengalami kendala pada jaringan internet. Ada pula kendala mengenai fasilitas yang dimiliki peserta didik, yakni tidak semua peserta didik memiliki fasilitas sendiri, ada beberapa yang harus bergantian dengan saudaranya dalam penggunaan handphone. Kendala selanjutnya adalah untuk menggunakan aplikasi zoom dan google meet masih perlu sosialisasi dan parenting terhadap semua pihak, sehingga dalam kondisi yang serba cepat Kepala Sekolah bersama Guru SD Muhammadiyah Program Khusus Andong memutuskan untuk menggunakan aplikasi yang sudah umum dan dikenali oleh peserta didik maupun wali murid".

Hal serupa juga disampaikan oleh guru pendamping, beliau menyatakan sebagai berikut:

"Kendala yang pertama adalah minimnya pelatihan untuk kami, karena munculnya pandemi yang tiba-tiba membuat kami hanya belajar secara otodidak. Kedua adalah jaringan dari sebagian peserta didik yang terganggu, mengingat wilayahnya tempat tinggalnya juga masih susah untuk mengakses jaringan. Ketiga adalah sebagian peserta didik kami terbatas juga secara fasilitas, dalam artian dalam mengaksees handphone harus bergantian dengan saudaranya yang masih sama-sama sekolah".

Kendala yang disampaikan oleh guru kelas II dan guru pendamping tersebut merupakan tantangan tersendiri bagi guru untuk dapat mengatasi dan memperbaiki setiap proses pada pelaksanaan pembelajaran daring. Minimnya pelatihan tentang pelaksanaan pembelajaran daring memang menjadi kendala utama, namun berbekal semangat dan kerja sama, pelatihan bisa didapatkan melalui berbagai sumber secara mandiri.

Selanjutnya adalah kendala teknis mengenai jaringan dan fasilitas media yang dimiliki oleh peserta didik, penyesuaian waktu, dan usaha yang dilakukan guru dalam penggunaan media yang ringan dan mudah diakses juga memberikan solusi bagi peserta didik maupun wali murid untuk mengikuti pelaksanaan pembelajaran selama pembelajaran daring.

Terdapat pula faktor pendukung yang ikut mensukseskan pelaksanaaan program pembentukan karakter disiplin peserta didik selama pembelajaran daring di SD 
Muhammadiyah Program Khusus Andong. Berikut ini faktor pendukung yang disampaikan oleh ibu guru kelas II dalam kutipan hasil wawancara dengan peneliti.

"Adanya fasilitas penunjang dari sekolah untuk dimanfaatkan guru dalam perencanaan maupun pelaksanaan kegiatan. Faktor pendukung selanjutnya adalah dukungan dari wali murid yang telah bekerja keras untuk terus mengontrol dan mendampingi kegiatan peserta didik selama pembelajaran daring, terutama kolaborasi untuk menyukseskan program pembentukan karakter disiplin peserta didik. Wali murid dari pagi hingga malam selalu melaporkan kegiatan peserta didik baik melalui foto, video, dan melalui buku kontrol atau buku kendali yang telah diisi dengan jujur oleh putra-putrinya kemudian dikirim setiap malam kepada guru kelas dan guru pendamping sebagai bahan evaluasi mengenai karakter disiplin peserta didik".

Hal senada juga disampaikan oleh guru kelas dalam kutipan berikut:

"Faktor pendukung selama ini adalah adanya dukungan dari sekolah, dengan disediakannnya sarana seperti komputer, camera, wifi, dan laptop yang bisa kami gunakan selama pembelajaran daring. Dukungan dari wali murid juga sangat tinggi, wali murid ikut mendampingi, dan membing putra-putrinya, serta berkolaborasi dengan baik pada setiap pembelajaran".

Dari pernyataan guru kelas dan guru pendamping tersebut menjelaskan bahwa pendidikan anak adalah tanggung jawab bersama antara sekolah dan lingkungan keluarga. Komunikasi dan kolaborasi yang baik dari guru dengan wali murid adalah faktor yang sangat penting dalam pelaksanaan program pembentukan karakter disiplin peserta didik selama pembelajaran daring, ditambah lagi dengan adanya dukungan dari sekolah mengenai sarana yang bisa digunakan guru selama pembelajaran daring.

Dari hasil observasi, terdapat pula upaya guru untuk membentuk karakter disiplin peserta didik dengan berkomunikasi secara intensif bersama wali murid setiap hari. Guru juga selalu berkomunikasi melalui whatsapp grup kelas selain pada jam pembelajaran untuk memberikan motivasi, nasihat, dan penekanan kepada peserta didik untuk membiasakan kegiatan-kegiatan, seperti murojaah, mengaji setiap habis maghrib, melaksanakan sholat wajib, sholah sunnah dhuha dengan tepat waktu, membantu orang tua, dan menggosok gigi sebelum tidur. Pembiasaan tersebut dilakukan guru untuk membentuk karakter disiplin peserta didik sejak dini.

SD Muhammadiyah Program Khusus Andong telah berupaya memberikan layanan yang terbaik dalam pembentukan karakter disiplin peserta didik selama pembelajaran daring. Pengintegrasian pembelajaran dengan nilai karakter disiplin, pembiasaan ibadah wajib dan sunnah tepat waktu, pembelajaran dengan berbagai inovasi, reward dan punishment yang mendidik, dan media buku kontrol atau buku kendali yang menghubungkan antara guru dengan orang tua.

\subsubsection{Evaluasi}

Berdasarkan hasil observasi yang dilakukan oleh peneliti terdapat tiga teknik evaluasi yang dilakukan guru dalam program pembentukan karakter disiplin peserta didik selama pembelajaran daring. Pertama, berdasarkan pelaksanaan, guru melakukan evaluasi dengan teknik pengamatan, yakni mengamati dan mencatat mengenai sikap 
disiplin peserta didik selama mengikuti pembelajaran daring dari awal pembelajaran hingga akhir. Kedua adalah dengan layanan layanan konsultasi antara guru dengan wali murid setiap pekan sekali. Layanan konsultasi tersebut diadakan secara luring dan daring bagi wali murid dan peserta didik. Teknis pelaksanaan layanan konsultasi adalah guru memberikan jadwal kepada wali murid secara bergantian setiap akhir pekan untuk berkonsultasi mengenai karakter disiplin peserta didik selama pembelajaran daring, baik secara daring maupun luring.

Dari hasil konsultasi antara guru dengan wali murid tersebut dijadikan sebagai dasar evaluasi dalam program pembentukan karakter disiplin peserta didik selama pembelajaran daring. Teknik evaluasi yang ketiga adalah melalui buku kontrol peserta didik, buku kontrol berisi kegiatan sehari-hari peserta didik. Buku kontrol juga dijadikan dasar oleh guru untuk memberikan pesan dan nasihat dalam pembentukan karakter disiplin peserta didik selama pembelajaran daring. Buku kontrol tersebut dilaporkan kepada guru setiap hari setelah mendapat paraf dari orang tua, pelaporan buku kontrol dengan cara difoto dan dikirim ke whatsapp group kelas.

Hal tersebut juga didukung oleh pernyataan dari guru kelas dalam kutipan hasil wawancara berikut ini:

"Teknik evaluasi yang kami gunakan adalah pengamatan, konsultasi dengan wali murid, dan melalui buku kontrol peserta didik. Teknik pengamatan kami lakukan saat pelaksanan pembelajaran. Teknik konsultasi adalah layanan yang diselenggarakan setiap pekan satu kali antara guru kelas dan guru pendamping dengan wali murid serta peserta didik, pelaksanaan konsultasi ini secara luring maupun daring sesuai dengan kondisi dari wali murid dan peserta didik. Luring dilaksanakan dengan protokol kesehatan yang ketat dari pihak sekolah, namun apabila daring bisa melalui media whatsapp atau telephone. Teknik yang terakhir adalah buku kontrol peserta didik yang berisi kegiatan peserta didik selama satu hari, baik kegiatan belajar maupun beribadah dari pagi hingga malam. Teknik pelaporan buku kontrol adalah dengan difoto dan dikirim ke whatsapp grup setelah diisi oleh peserta didik".

Adapun rubrik penilaian yang digunakan oleh guru kelas dan guru pendamping kelas dua adalah papan reward atau papan prestasi dengan menggunakan emotikon. Berdasarkan hasil observasi, peneliti mendeskripsikan bahwa emotikon bintang berarti nilai disiplin peserta didik adalah $\mathrm{A}$, emotikon senyum adalah $\mathrm{B}$, dan emotikon dengan hidung panjang berarti $\mathrm{C}$. Peserta didik yang mendapatkan nilai $\mathrm{C}$ perlu diberikan tindakan khusus atau tindak lanjut dari guru untuk pembimbingan lebih lanjut.

Pada saat melakukan observasi, peneliti juga mendapatkan dokumentasi berupa papan prestasi. Papan prestasi tersebut terdapat di dalam ruang kelas. Papan prestasi dengan beberapa gambar emotikon tersebut merupakan hasil capaian prestasi disiplin peserta didik selama pembelajaran daring. Guru selalu memberikan laporan disiplin dengan memberikan dokumentasi papan prestasi kepada peserta didiki melalui whatsapp group. Berikut ini dokumentasi rubrik penilaian karakter disiplin peserta didik dalam bentuk papan prestasi. 


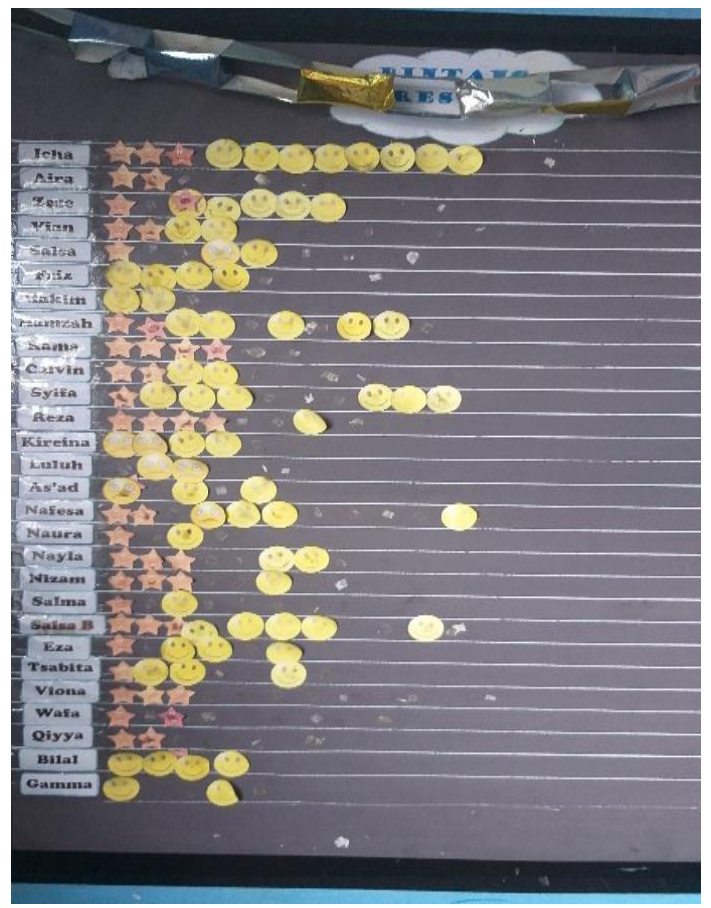

Gambar 3. Papan Prestasi

Berdasarkan hasil wawancara, observasi, dan dokumentasi tersebut, terdapat tiga teknik evaluasi, yaitu pengamatan, layanan konsultasi, dan buku kontrol. Evaluasi tersebut bersifat kolaboratif karena tidak hanya bersifat sepihak dari guru saja, melainkan juga terdapat teknik evaluasi yang melibatkan wali murid. Teknik ini adalah hal yang baru dan akan berdampak positif akan perkembangan peserta didik. Selain teknik yang bagus pada tahap evaluasi, rubrik penilaian yang digunakan juga menarik, karena menggunakan peraga yang dapat meningkatkan motivasi peserta didik, yaitu berupa papan prestasi yang berisi emotikon. Hal ini sesuai dengan karakteristik peserta didik kelas II masih menyukai reward yang diberikan oleh gurunya.

\subsubsection{Tindak Lanjut}

Tahap tindak lanjut adalah tahapan yang dilakukan untuk menyikapi hasil evaluasi. Setelah melakukan evaluasi, guru hendaknya melihat kembali tahap perencanaan, pelaksanaan, dan evaluasi. Dari data penelitian yang diperoleh oleh peneliti melalui observasi dan dokumentasi kepada guru kelas serta guru pendamping, tindak lanjut yang dilaksanakan oleh guru kelas dan guru pendamping kepada peserta didik yang kurang disiplin selama pembelajaran daring adalah dengan memberikan layanan konseling secara privat melalui video call. Saat video call guru memberikan nasihat, motivasi, dan himbauan kepada peserta didik agar lebih disiplin dalam menjalani kegiatan-kegiatannya di rumah. Metode ini juga dimanfaatkan oleh guru untuk mendengarkan keluhan dari peserta didik mengenai alasan telat mengumpulkan tugas, telat mengikuti pembelajaran, telat mengirim laporan buku kontrol, dan kendalakendala lainnya selama pembelajaran daring. Peneliti juga memperoleh dokumentasi pendukung ketika guru melakukan video call bimbingan secara privat kepada peserta didik. Dokumentasi guru saat melaksanakan kegiatan konseling adalah sebagai berikut: 


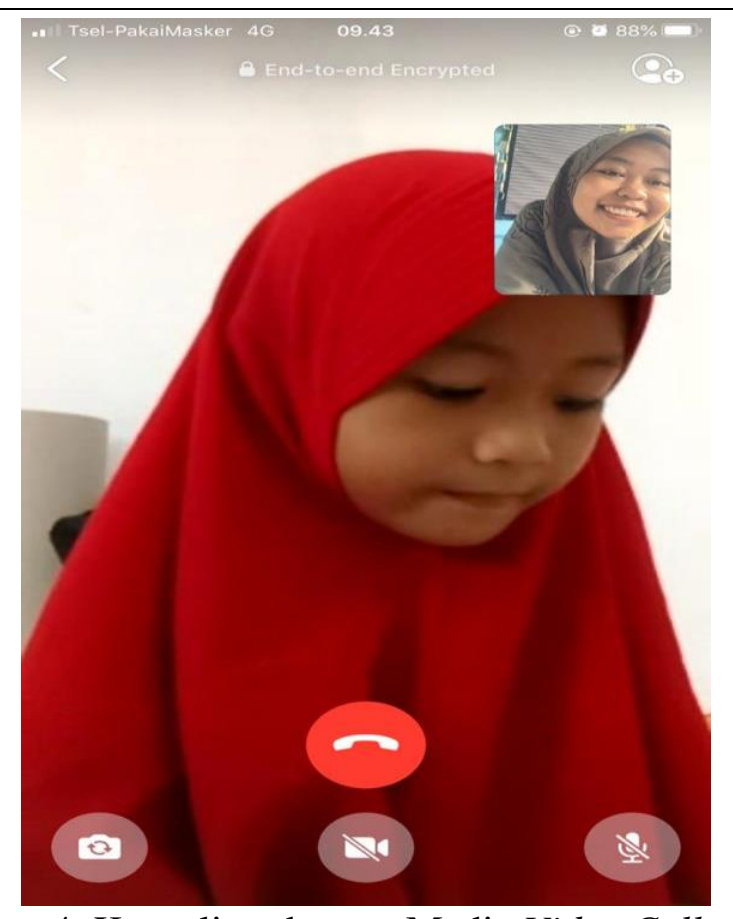

Gambar 4. Konseling dengan Media Video Call

\subsection{Pembahasan}

Penelitian yang dilakukan oleh peneliti memiliki nilai kebaharuan, yakni program pembentukan karakter peserta didik selama pembelajaran daring di SD Muhammadiyah Program Khusus Andong melalui empat tahap tahap, yaitu tahap perencanaan, pelaksanaan, evaluasi, dan refleksi. Penelitian ini sebagai tambahan temuan kebaharuan dari penelitian yang dilakukan oleh Wuryandani, Maftuh, Sapriya, \& Budimansyah (2014) yang menyebutkan bahwa implementasi pendidikan karakter disiplin di SD Muhammadiyah Sapen dilaksanakan dengan sembilan kebijakan, yakni: (1) menciptakan program pendidikan karakter, (2) menetapkan tata tertib sekolah serta tata tertib kelas, (3) melaksanakan sholat sunnah dhuha dan sholat wajib dhuhur secara berjamaah, (4) pembuatan pos afektif di masing-masing kelas, (5) mengawasi tingkah laku disiplin peserta didik di rumah dengan buku kontrol, (6) memberi pesan afektif di sudut-sudut sekolah, (7) berkolaborasi dengan orang tua, (8) berkolaborasi dengan komite sekolah, dan (9) menciptakan susasana yang kondusif di kelas.

Berdasarkan data yang diperoleh, pada tahap pertama yaitu perencanaan program pembentukan karakter disiplin di SD Muhammadiyah Program Khusus Andong guru membuat RPP dengan mengintegrasikan setiap langkah-langkah pembelajaran pada karakter disiplin. Hal ini sejalan dengan hasil penelitian dari Yuningsih, Nurjaya, \& Wisudariani (2019) yang menyebutkan bahwa dalam pengintegrasian nilai karakter tertuang dalam RPP. Nilai-nilai karakter dapat diintegrasikan di langkah-langkah pembelajaran dari kegiatan inti dan penutup. Guru kelas dan guru pendamping juga membuat suatu video pembelajaran sesuai dengan RPP untuk diunggah di youtube kemudian dibagikan di whatsapp group kelas. Pembuatan video ini sebagai ganti pembelajaran tatap muka di kelas, sehingga peserta didik dapat menyimak materi pelajaran dan arahan dari guru melalui video. Hal serupa juga diutarakan oleh Syafi'i, Sa'diyah, Wakhidah, \& Umah (2020) dalam penelitiannya yang menyebutkan bahwa video pembelajaran daring dibuat oleh guru secara bergantian, kemudian dibagikan melalui whatsapp group. Pada tahap perencanaan, guru juga 
membuat rencana untuk memberikan layanan konseling terhadap peserta didik yang didampingi dengan orang tua. Layanan ini dilakukan sebagai bentuk kolaborasi antara guru dan orang tua.

Pada tahap pelaksanaan guru menggunakan media whatsapp group untuk memulai pembelajaran dengan absen pagi pada peserta didik. Whatsapp group juga dimanfaatkan guru untuk meminta laporan pembiasaan kegiatan pagi seperti di sekolah, contohnya sholat dhuha, membantu orang tua dengan menyapu, mencuci piring, atau melipat baju. Laporan kegiatan dikirim dengan foto dari setiap aktivitas peserta didik. Whatsapp group menjadi media pembelajaran yang bisa diakses oleh semua peserta didik dan orang tua di rumah. Whatsapp group dapat membantu peserta didik dan menjadi solusi dalam pembelajaran daring, yakni melalui whatsapp group guru dan peserta didik dapat berkomunikasi, bertukar fikiran, dan bisa membuat forum diskusi belajar (Iskandar, 2020; Mu'minah \& Sugandi, 2021). Dalam bentuk implementasi pembelajaran di SD Muhammadiyah Program Khusus Andong selain menggunakan whatsapp group, guru juga berinovasi menggunakan video pembelajaran yang telah dibuat dan diunggah di youtube. Video call secara berkelompok juga dilakukan guru untuk membentuk karakter disiplin peserta didik, layanan ini juga dilakukan dengan tujuan untuk memberikan umpan balik kepada peserta didik mengenai kedisiplinannya dalam mengikuti pembelajaran melalui youtube. Video call juga dimanfaatkaan guru untuk memberikan reward and punishment pada peserta didik yang melaksanakan kedisiplinan dengan baik dan peserta didik yang kurang disiplin. Pemberian reward and punishment dilakukan guru agar peserta didik termotivasi untuk selalu membiasakan disiplin dalam segala hal, baik di dalam pembelajaran maupun di luar pembelajaran. Metode reward and punishment dalam membentuk karakter disipin peserta didik juga dijelaskan oleh Sari, Jamaludin, \& Taufik (2019) yang menyebutkan bahwa pemberian reward and punishment pada peserta didik dapat menekankan sikap disiplin, menumbuhkan semangat, dan menumbuhkan kejujuran.

Ketiga adalah evaluasi. Evaluasi program pembentukan karakter disiplin peserta didik selama pembelajaran daring berdasarkan hasil penelitian di SD Muhammadiyah Program Khusus Andong dilakukan dalam bentuk non tes dengan tiga teknik. Pertama yaitu pengamatan pada peserta didik, kedua dengan buku kontrol, dan ketiga dengan bimbingan konseling yang berkolaborasi antara guru dan orang tua atau wali murid. Evaluasi sikap dengan teknik non tes juga pernah dijelaskan oleh Magdalena, Oktavia, Ismawati, \& Alia (2021) dalam penelitiannya menyebutkan bahwa teknik evaluasi non tes yang dapat digunakan dalam penilaian sikap peserta didik, seperti wawancara dengan peserta didik dan wali murid, observasi atau pengamatan terhadap peserta didik, penilaian portofolio, penilaian diri, dan penilaian antar teman.

Keempat adalah tindak lanjut. Tindak lanjut dilakukan atas dasar evaluasi yang dilakukan guru. Tindak lanjut dilakukan guru untuk membimbing, menasihati, dan memotivasi peserta didik. Selain memberikan pendampingan, tindak lanjut juga dimanfaatkan oleh guru untuk mendengarkan keluhan mengenai kendala-kendala apa saja yang dialami peserta didik selama pembelajaran daring yang mengakibatkan peserta didik tersebut tidak disiplin.

\section{Simpulan}

Berdasarkan hasil penelitian yang telah diuraikan, maka dapat disimpulkan bahwa program pembentukan karakter disiplin peserta didik selama pembelajaran daring di SD Muhammadiyah Program Khusus Andong sudah berjalan dengan baik. 
Program pembentukan karakter disiplin peserta didik selama pembelajaran daring dilaksanakan dengan tersistem dan terstruktur, yaitu dengan empat tahap. Tahapantahapan tersebut adalah tahap perencanaan, tahap pelaksanaan, tahap evaluasi, dan tahap tindak lanjut. Program pembentukan karakter disiplin peserta didik selama pembelajaran daring di SD Muhammadiyah Program Khusus Andong pada hakikatnya dilaksanakan guru dengan membiasakan kegiatan-kegiatan positif setiap hari dengan kontrol ketat dari guru. Keberhasilan program tersebut disebabkan oleh kolaborasi yang baik antara kepala sekolah dengan guru, guru kelas dengan guru pendamping, dan kerja sama yang baik antara guru kelas, serta pendamping dengan wali murid. Metode yang digunakan guru juga menarik dan menampilkan inovasi-inovasi untuk mendukung lancarnya program pembentukan karakter disiplin selama pembelajaran daring di SD Muhammadiyah Program Khusus Andong. Ketuntasan layanan selama pembelajaran daring menggambarkan bahwa sekolah mampu beradaptasi dan tetap memberi layanan yang prima dalam keadaan kritis seperti saat pembelajaran daring yang diakibatkan oleh pandemi Covid-19.

\section{Daftar Pustaka}

Ahmad, M., Qamar, T., \& Abbasi, N. N. (2021). Intrinsic or Extrinsic Discipline: Case Study of Public Secondary Schools in Punjab, Pakistan. Pakistan Journal of Educational Research, 4(1), 162-177. https://doi.org/10.52337/PJER.V4I1.147

Anhusadar, L. O. (2020). Persepsi Mahasiswa PIAUD terhadap Kuliah Online di Masa Pandemi Covid-19. KINDERGARTEN: Journal of Islamic Early Childhood Education, 3(1), 44-58. https://doi.org/10.24014/KJIECE.V3I1.9609

Aulina, C. N. (2013). Penanaman Disiplin pada Anak Usia Dini. PEDAGOGIA: Jurnal Pendidikan, 2(1), 36-49. https://doi.org/10.21070/pedagogia.v2i1.45

Bajri, N. S., Oktaviani, H., Luzyawati, L., Eka, L., \& Nurfebriani, I. (2021). Student's Discipline in Biology Online Learning in SMA Negeri 1 Sindang. Report of Biological Education, 2(1), 11-18. https://doi.org/10.37150/REBION.V2I1.1157

Hermanto, Japar, M., \& Utomo, E. (2019). Implementasi Pembelajaran Ilmu Pengetahuan Sosial dalam Membentuk Karakter Siswa. AULADUNA: Jurnal Pendidikan Dasar Islam, 6(1), 1-6. https://doi.org/10.24252/AULADUNA. V6I1A1.2019

Iskandar, R. (2020). Penggunaan Group Whatsapp sebagai Media Pembelajaran Terhadap Peserta Didik DTA AT-Tawakal Kota Bandung. Comm-Edu (Community Education Journal), 3(2), 97-101. https://doi.org/10.22460/COM M-EDU.V3I2.3778

Jannah, N., \& Supriyanto. (2021). Strategi Membangun Budaya Disiplin Siswa di Era Pandemi Covid-19. Jurnal Inspirasi Manajemen Pendidikan, 9(3), 604-618. https://ejournal.unesa.ac.id/index.php/inspirasi-manajemen-pendidikan/article/vi ew/39643

Magdalena, I., Oktavia, A., Ismawati, S., \& Alia, F. (2021). Penggunaan Evaluasi Non Tes dan Hambatannya dalam Pembelajaran di SDS Sari Putra Jakarta Barat. PENSA, 3(1), 67-75. https://doi.org/10.36088/PENSA.V3I1.1156

Mu'minah, I. H., \& Sugandi, M. K. (2021). Application WhatsApp as a Learning Media in Pandemic Covid-19. Jurnal Bio Educatio, 6(1), 68-81. https://doi.org/10.31 949/BE.V6I1.3032

Mustaqim, M. (2015). Model Pendidikan Karakter Terintegrasi pada Pembelajaran di Pendidikan Dasar. ELEMENTARY: Islamic Teacher Journal, 3(1), 157-170. 
https://doi.org/10.21043/ELEMENTARY.V3I1.1448

Mustikaningrum, G., Pramusinta, L., Buamona, S. A. M. U., Cahyadi, E., \& Istiqomah, W. (2020). Implementasi Pendidikan Karakter Terintegrasi Kurikulum dan Metode pada Masa Pandemi Covid-19. AULADUNA: Jurnal Pendidikan Dasar Islam, 7(2), 154-164. https://doi.org/10.24252/10.24252/AULADUNA.V7I2A5. 2020

Nisa, F., Fathurohman, I., \& Setiawan, D. (2021). Karakter Kedisiplinan Belajar Anak SDN 2 Muryolobo pada Masa Pembelajaran Daring. Jurnal Inovasi Penelitian, 2(4), 1179-1186. https://doi.org/10.47492/JIP.V1I4.754

Novianti, R., \& Garzia, M. (2020). Parental Engagement in Children's Online Learning During Covid-19 Pandemic. Journal of Teaching and Learning in Elementary Education (JTLEE), 3(2), 117-131. https://doi.org/10.33578/JTLEE.V3I2.7845

Obadire, O. T., \& Sinthumule, D. A. (2021). Learner Discipline in the Post-Corporal Punishment Era: What an Experience!. South African Journal of Education, 41(2), 1-8. https://doi.org/10.15700/saje.v41n2a1862

Purandina, Y. I. P., \& Winaya, A. I. M. (2020). Pendidikan Karakter di Lingkungan Keluarga selama Pembelajaran Jarak Jauh pada Masa Pandemi Covid-19. Cetta: Jurnal Ilmu Pendidikan, 3(2), 270-290. https://doi.org/10.37329/CETTA.V3 I 2.454

Rahayu, D., Narimo, S., Fathoni, A., Rahmawati, L. E., \& Widiyasari, C. (2020). Pembentukan Karakter Siswa Berorientasi Higher Order Thinking Skils (HOTS) di Sekolah Dasar. ELSE (Elementary School Education Journal): Jurnal Pendidikan dan Pembelajaran Sekolah Dasar, 4(1), 109-118. https://doi.org/ 10.30651/ELSE.V4I1.4071

Rasmitadila, Aliyyah, R. R., Rachmadtullah, R., Samsudin, A., Syaodih, E., Nurtanto, M., \& Tambunan, A. R. S. (2020). The Perceptions of Primary School Teachers of Online Learning during the Covid-19 Pandemic Period: A Case Study in Indonesia. Journal of Ethnic and Cultural Studies, 7(2), 90-109. https://doi.org/10.29333/EJECS/388

Rigianti, H. A. (2020). Kendala Pembelajaran Daring Guru Sekolah Dasar di Kabupaten Banjarnegara. Elementary School: Jurnal Pendidikan dan Pembelajaran Ke-SDan, 7(2), 297-302. https://doi.org/10.31316/ESJURNAL.V7I2.768

Sari, D. A., Jamaludin, U., \& Taufik, M. (2019). Penguatan Pendidikan Karakter Peserta Didik melalui Pemberian Reward dan Punishment di SD Unggulan Uswatun Hasanah. Attadib: Journal of Elementary Education, 3(1), 1-16. https://doi.org/ 10.32507/ATTADIB.V3I1.456

Sudarmo, \& Muslimah. (2020). Teacher's Leadhership Competency in Managing Online Instruction during the Pandemic Disruption in Indonesia. Nidhomul Haq: Jurnal Manajemen Pendidikan Islam, 5(3), 430-445. https://doi.org/10.31538/ NDH.V5I3.1018

Sugiarto, A. P., Suyati, T., \& Yulianti, P. D. (2019). Faktor Kedisiplinan Belajar pada Siswa Kelas X SMK Larenda Brebes. Mimbar Ilmu, 24(2), 232-238. https://doi.org/10.23887/MI.V24I2.21279

Sugiarto, E. (2015). Menyusun Proposal Penelitian Kualitatif: Skripsi dan Tesis. Suaka Media.

Sugiyono. (2013). Metode Penelitian Pendidikan Pendekatan Kuantitatif, Kualitatif, dan $R \& D$. Alfabeta.

Syafi'i, I., Sa'diyah, C., Wakhidah, E. W., \& Umah, F. M. (2020). Penerapan Video 
Pembelajaran Daring Anak Usia Dini pada Masa Pandemi Covid-19. Al-Athfaal: Jurnal Ilmiah Pendidikan Anak Usia Dini, 3(2), 140-160. https://doi.org/ 10.24042/AJIPAUD.V3I2.7315

Widagdo, W., Nurdyansyah, \& Faujiyah, Y. (2020). Implementation of Character Education Through Coaching Discipline of Students. Proceedings of The ICECRS, 5, 1-8. https://doi.org/10.21070/icecrs2020407

Wuryandani, W., Maftuh, B., Sapriya, \& Budimansyah, D. (2014). Pendidikan Karakter Disiplin di Sekolah Dasar. Cakrawala Pendidikan, 33(2), 286-295. https://doi. org/10.21831/cp.v2i2.2168

Yuningsih, L. A., Nurjaya, I. G., \& Wisudariani, N. M. R. (2019). Integrasi Pendidikan Karakter pada Pembelajaran Bahasa Indonesia di SMP Negeri 2 Sawan. Jurnal Pendidikan Bahasa dan Sastra Indonesia Undiksha, 9(1), 152-161. https://doi. org/10.23887/JJPBS.V9I1.20754

Zakaria, \& Maulida, U. (2021). Penanaman Karakter Gemar Membaca melalui One Day One Dongeng pada Masa pandemi Covid-19. AULADUNA: Jurnal Pendidikan Dasar Islam, 8(1), 66-76. https://doi.org/10.24252/AULADUNA.V8I1A6.2021 